\title{
Shakespeare, Jonson, and the Invention of the Author
}

\author{
IAN DONALDSON \\ Fellow of the Academy
}

The lives AND CAREers of Shakespeare and Ben Jonson, the two supreme writers of early modern England, were intricately and curiously interwoven. Eight years Shakespeare's junior, Jonson emerged in the late 1590 s as a writer of remarkable gifts, and Shakespeare's greatest theatrical rival since the death of Christopher Marlowe. Shakespeare played a leading role in the comedy that first brought Jonson to public prominence, Every Man In His Humour, having earlier decisively intervened-so his eighteenth-century editor, Nicholas Rowe, relates - to ensure that the play was performed by the Lord Chamberlain's Men, who had initially rejected the manuscript. ${ }^{1}$ Shakespeare's name appears alongside that of Richard Burbage in the list of 'principal tragedians' from the same company who performed in Jonson's Sejanus in 1603, and it has been conjectured that he and Jonson may even have written this play together. ${ }^{2}$ During the years of their maturity, the two men continued to observe

Read at the Academy 25 April 2006.

' The Works of Mr William Shakespeare, ed. Nicholas Rowe, 6 vols. (London, printed for Jacob Tonson, 1709), I, pp. xii-xiii. On the reliability of Rowe's testimony, see Samuel Schoenbaum, Shakespeare's Lives (Oxford, 1970), pp. 19-35.

${ }^{2}$ The list is appended to the folio text of the play, published in 1616. For the suggestion that Shakespeare worked with Jonson on the composition of Sejanus, see Anne Barton, Ben Jonson: Dramatist (Cambridge, 1984), pp. 93-4. Scholarly opinion continues to favour George Chapman as the 'second pen' who assisted Jonson with this play. Rudyard Kipling attractively imagines Shakespeare and Jonson together translating a chapter of Isaiah for the King James Bible: 'Proofs of Holy Writ', The Sussex Edition of the Complete Works in Prose and Verse of Rudyard Kipling, 35 vols. (London, 1937-9), vol. 30, Uncollected Prose (1938), 2, first published in The Strand Magazine, April 1934. 
each other's practice with sharp attention, as the evidence of echoing words, phrases, and structural devices throughout their work attests. ${ }^{3}$ Though their professional pathways, like their styles of writerly selfpresentation, diverged in ways I want now to describe, the two men clearly continued to act, each to the other, as a powerful creative stimulant, irritant, and example.

Shakespeare stands as the archetypal model of what the American critic Hugh Kenner, speaking of T. S. Eliot, was to term 'the invisible poet'. $\mathrm{He}$ is the deus absconditus of his own creative world, whose seemingly mysterious and illegible personality has prompted centuries of ingenious speculation; whose very identity is still vigorously disputed in monographs bearing such titles as The Shakespeare Enigma; The Shakespeare Conspiracy; Shakespeare, Thy Name is Marlowe; Was Shakespeare Shakespeare? A Lawyer Reviews the Evidence. He is the writer who seems, in the suggestive title of Jorge Luis Borges's haunting fable, everything and nothing, his personal identity so widely dispersed throughout-so fully projected into-the characters who inhabit his imaginative world that it is seemingly nowhere ultimately to be found. ${ }^{4}$

Jonson is a writer of a quite different kind, who manifests himself (or so it seems) throughout his work, forever creating and presenting versions and portraits of himself. $\mathrm{He}$ is, one might say, the visible poet, whose writings pronounce his personal opinions, his literary ambitions, his material needs, his physical appearance, his very name; who incorporates and instantiates himself within the literary text:

${ }^{3}$ See S. Musgrove, Shakespeare and Jonson, The Macmillan Brown Lectures 1957 (Folcroft, PA, 1975); Ian Donaldson, 'Looking Sideways: Jonson, Shakespeare, and the Myths of Envy', in Takashi Kozuka and J. R. Mulryne (eds.), Shakespeare, Marlowe, Jonson: New Directions in Biography (Aldershot, 2006), pp. 241-57.

${ }^{4}$ Hugh Kenner, The Invisible Poet: T. S. Eliot (London, 1960), Peter Dawkins, The Shakespeare Enigma (London, 2004); Graham Phillips and Martin Keatman, The Shakespeare Conspiracy (Post Falls, ID, 1994); David Rhys Williams, Shakespeare, Thy Name is Marlowe (New York, Philosophical Library, 1966); Milward W. Martin, Was Shakespeare Shakespeare? A Lawyer Reviews the Evidence (New York, 1965); Jorge Luis Borges, 'Everything and Nothing' in Donald A. Yates and James E. Irby (eds.), Labyrinths: Selected Stories and Other Writings (Harmondsworth, 1970), pp. 284-5. 
... being a tardy, coid,

Unprofitable chattel, fat and old,

Laden with belly, and doth hardly approach

His friends, but to break chairs or crack a coach.

(The Underwood, 56. 7-10)

Rest in soft peace, and, asked, say here doth lie

Ben Jonson his best piece of poetry ...

(Epigrams, 45. 9-10)

Father John Burgess

Necessity urges

My woeful cry,

To Sir Robert Pye;

And that he will venture

To send my debenture.

Tell him his Ben

Knew the time, when

He loved the muses;

Though now he refuses

To take apprehension

Of a year's pension,

And more is behind. . .

(The Underwood, 57, 1-13)

It is hard to think of another poet writing in English - not even John Skelton, whose skittish measures Jonson follows in the lines just quoted, or Yeats, who studied Jonson's verse with such attention - who so frequently offers himself as the object or subject of his own poetic scrutiny. ${ }^{6}$

This contrast between the two writers - the one, seemingly absent from the text; the other, seemingly immanent; more pressingly, more personally, at our side - assumes a particular interest in relation to the central question I want to pursue in this lecture: the emergence of an early modern concept of authorship. Shakéspeare significantly uses the word

${ }^{5}$ All quotations from Jonson are given in modernised form (as they will appear in the forthcoming Cambridge Edition of the Works of Ben Jonson, ed. David Bevington, Martin Butler, and Ian Donaldson: 25 vols., Cambridge, 2008) but linked for ease of reference to the old-spelling edition of C. H. Herford and Percy and Evelyn Simpson, Ben Jonson, 11 vols. (Oxford, 1925-52). ${ }^{6}$ Jonson introduces John Skelton as a character in his 1624 masque, The Fortunate Isles, where he again adopts Skeltonic verse forms. Yeats immersed himself in Jonson's work in 1905/6 (R. F. Foster, W. B. Yeats: A Life, 1: The Apprentice Mage 1865-1914 (Oxford, 1997), pp. 337, 345 and n.) and his verse frequently echoes Jonsonian lines and phrases: e.g. 'dull ass's hoof' ('While I, from that reed-throated whisperer', line 5, W. B. Yeats, Collected Poems (London, 1963), p. 143, from Poetaster, Apologetical Dialogue, 238-9 and The Underwood, 23. 35-6); 'household spies' ('Parting', line 3, Yeats, Collected Poems, p. 311, from Volpone, 3. 7.177 and The Forest, 5. 12). 
'author' self-referentially on only two occasions in the entire canon, and then with an air of mild self-deprecation. 'One word more, I beseech you', says the speaker of the Epilogue of 2 Henry IV, 'If you be not too much cloy'd with fat meat, our humble author will continue the story, with Sir John in it, and make you merry with fair Katherine of France; where (for anything I know) Falstaff shall die of a sweat, unless already a be kill'd with your hard opinions' (lines 26-31). The word emerges again in the final Chorus to Henry $V$ :

Thus far, with rough and all unable pen

Our bending author hath pursu'd the story,

In little room confining mighty men,

Mangling by starts the full course of their glory. $(1-4)^{7}$

This author seems to apologise humbly, bendingly, through his actors, not just (in time-honoured style) for a lack of_personal talent, but_one might almost say - for the very genre in which he dares to write; for the physical limitations of the playhouse in which he works, and the dubious status of his chosen literary vehicle: the drama. Such diffidence speaks to an age in which plays, in the scale of literary creation, were not highly regarded; in which Sir Thomas Bodley, with fatal lack of speculative instinct, famously instructed his librarian not to bother collecting mere playbooks for his grand new repository in Oxford; in which dramatic composition was still largely a backroom and anonymous affair. ${ }^{8}$ The actual identity of the humble author of 2 Henry $I V$, the bending author of Henry $V$, would probably have been unknown to the majority of playgoers in the 1590s. Nowhere in the theatre of this time was the author's name displayed or evident. Theatre programmes did not yet exist, and while theatrical playbills advertising the pieces to be performed might include the titles of the works in question and the names of one or two

${ }^{7}$ See Mark Rose's lively study, Authors and Owners: The Invention of Copyright (Cambridge, MA, 1993), p. 26. Quotations from The Riverside Shakespeare, ed. Harry Levin and others (Boston, etc., 1974).

${ }^{8}$ Letters of Sir Thomas Bodley to Thomas James, Keeper of the Bodleian Library, ed. G. W. Wheeler (Oxford, 1926), pp. 219-20; G. E. Bentley, The Profession of Dramatist in Shakespeare's Time, 1590-1642 (Princeton, NJ, 1971), chap. 2, 'Status of Dramatists'. As Heidi Brayman Hackel has shown, Bodley's disapproval of playbooks was not widely shared amongst private collectors, but may have reflected particular views about the composition of a university collection, and the disproportionate space such items might occupy: "Rowme" of Its Own: Printed Drama in Early Libraries', chap. 7 in John D. Cox and David Scott Kastan (eds.), A New History of Early English Drama (New York, 1997), pp. 113-30. Bequests to the Bodleian Library from collectors of drama such as Robert Burton were soon to erode the founder's original policy: see Ian Philip, The Bodleian Library in the Seventeenth and Eighteenth Centuries (Oxford, 1983). 
principal actors - who were often well known to the play-going publicthe authors' names were not thought worthy of mention in playbills until the final years of the seventeenth century, when their public accreditation attracted comment as something of a novelty. ${ }^{9}$ So far from constituting an 'enigma' or a 'conspiracy', Shakespeare's relative invisibility as a writer of plays was an unsurprising consequence of the working conditions of the theatre of his time. Like the musical composer (a word first recorded in the late 1590s) the dramatic author, as an accredited professional category and a person worthy of public notice, did not yet fully exist. ${ }^{10}$

There was not even yet a settled term to describe such a person. The words most commonly used in modern times to denote a writer of plays, dramatist and playwright, did not appear until after the Restoration, if the Oxford English Dictionary is to be trusted, and seem to have been slow even then to move into popular currency. 'Playwright', as it happensthe $O E D$ has missed these examples - is a word that is actually found in three epigrams written by Ben Jonson before 1612, where it is used as a term of unmitigated contempt. The word may perhaps be Jonson's invention. ${ }^{11}$ Here is one of the epigrams, 'To Playwright'.

${ }^{9}$ Commenting on a playbill accompanying a revival of The Double Dealer that bore the words, 'Written by Mr Congreve; with Severall Expressions omitted', John Dryden wrote to Mrs Steward (4 Mar. 1698/9) that 'the printing of an Authours name in a Play bill, is a new manner of proceeding, at least in England': Charles E. Ward (ed.), The Letters of John Dryden With Letters Addressed to Him (Durham, NC, 1942), letter 59, pp. 112-13; cit. Bentley, The Profession of Dramatist, pp. 60-1. Some awareness of the identity of the author must nevertheless be assumed in plays such as Dekker's Satiromastix, which tauntingly refers to Jonson's physical appearance and personal characteristics.

${ }^{10} O E D$ 's first example of 'composer' in its musicaĩ sense is from Thomas Morley's $A$ plaine and easie introduction to practicall musicke, 1597 . The word was also commonly used at this time in relation to a writer of literary works. On the nineteenth-century development of the concept of the musical composer (and the variety of terms preceding its establishment), see Lydia Goehr, The Imaginary Museum of Musical Works (Oxford, 1992).

${ }^{11}$ Another early occurrence of the word is to be found in the commendatory verses of 'Cygnus'-probably Jonson's friend, Hugh Holland-prefixed to the quarto edition of Sejanus in 1605, that distinguish, in Jonsonian style, the work of 'the deserving Author', from that of 'the crew / Of common playwrights' (Ben Jonson, ed. Herford and Simpson, 11. 314). In 1617 Henry Fitzgeffrey fleered at 'Crabbed (Websterio) The Play-wright, Cart-wright' ('Notes from Blackfryers', in Satyres and Satyricall Epigrams, Stationers' Register, 9 Oct. 1617). The dramatist John Webster ('Websterio') appears to have worked with his father in the family business in Cow Lane, building and hiring out coaches: see David Gunby, 'John Webster'; Oxford Dictionary of National Biography (Oxford, 2004). The gibe again demeaningly associates dramatic composition with manual labour. 
Playwright me reads, and still my verses damns:

He says I want the tongue of epigrams;

I have no salt: no bawdry, he doth mean;

For witty, in his language, is obscene.

Playwright, I loathe to have thy manners known

In my chaste book: profess them in thine own.

Epigrams, 49

This playwright presumptuously dares to pass judgement on a traditional poetic form, the epigram, of which, as a mere theatrical hack, he has no knowledge or understanding. From the second epigram addressed to the same figure, it is possible to deduce that the hack in question may have been John Marston, who did in fact write poetry as well as plays, though Jonson's neologism witheringly confines him to the theatre. 'Stagewright' is another, equally hostile Jonsonian term to describe the same kind of theatrical drudge. ${ }^{13}$ The suffix reveals Jonson's own valuation of much dramatic work in his day as menial labour, and also perhaps a lingering sensitivity about the trade he himself had not entirely yet abandoned. After leaving Westminster School, William Drummond of Hawthornden noted, Jonson 'was put to another craft (I think was to be a wright or bricklayer) which he could not endure'. Bricklaying was a craft to which, after various theatrical disasters, Jonson's critics were accustomed to suggest he might usefully return. ${ }^{14}$

Both Shakespeare and Jonson entered the theatre as actors, and moved into writing only by degrees. In the first unmistakable reference to Shakespeare after his arrival in London from the provinces, Robert Greene in 1592 famously describes him as a bombastic player and wouldbe writer, a stealer of the ideas of others, an 'upstart crow', 'beautified with our feathers'. He is (Greene goes on) 'an absolute Johannes Factotem' - a do-all, a Jack of all trades. ${ }^{15}$ Factotem here is an obvious term of abuse, and yet it would also in the years to come have reflected with increasing accuracy the sheer range of Shakespeare's professional

12 'Playwright, convict of public wrongs to men, / Takes private beatings, and begins again', etc. (Epigrams, 68. 1-2); Jonson told William Drummond of Hawthornden that 'He beat Marston, and took his pistol from him', Conversations with Drummond, line 125. 'Playwright' appears once more in Epigrams, 100.

13 'Ode. To Himself' (on The New Inn), line 35; OED's only example of the word.

${ }^{14}$ Conversations with Drummond, lines 196-7. Taunts about his work as a bricklayer dogged Jonson from early in his career (The Return from Parnassus, Part 2, lines 293-8, in Three Parnassus Plays, ed. J. B. Leishman (London, 1949)) until late in life: see Alexander Gill's verses, line 52, on The Magnetic Lady, ed. Peter Happé (Manchester and New York, 2000), p. 217.

${ }^{15}$ Robert Greene, Groats-worth of witte, bought with a million of Repentance (1592), sig. Flv. 
duties in the Lord Chamberlain's company, as player and shareholder, overseeing the hiring and payment of musicians and scribes and tiremen and stagehands and casual actors, the payment of rent, the division of income. Like Molière later in France, like Garrick and Sheridan later in England, Shakespeare led a busy and versatile professional life, in the midst of which, miraculously, he found time also to write his plays. Years later Ben Jonson was to find a similarly abusive term to describe his colleague Inigo Jones, who tried busily to commandeer all professional roles when staging their masques at court: Dominus Do-All. ${ }^{16}$

Jonson's own early work in the theatre had itself been various. Henslowe had soon begun to give him additional work, patching and mending old plays for revival, and working collaboratively with Thomas Dekker, Henry Chettle, Henry Porter, and others in his team on plays that Jonson chose significantly not to include amongst his later published work, and that are known today chiefly by their titles: Hot Anger Soon Cold, Page of Plymouth, Robert II, The King of the Scots' Tragedy. With such jointly written plays, it might often have been difficult to say precisely where responsibility for particular scenes, lines, and episodes finally lay. When Jonson and two fellow-actors from Pembroke's company, Robert Shaa and Gabriel Spencer, were incarcerated in Marshalsea Prison in 1597 following the performance of the notorious, now-lost satirical piece, The Isle of Dogs-co-written by Jonson and Thomas Nashe (who had prudently fled to the safety of Great Yarmouth) - all those concerned, including the actors, who may have added their own improvised material, seem sturdily to have denied responsibility for whatever it was that had caused the offence. This pattern was later repeated when Jonson and one of his two co-authors, George Chapman, were arrested following performances of another play which angered those in authority, Eastward Ho! In such contexts as these, the very notion of authorship seemed as elusive as some of the authors themselves (John Marston, the third collaborator on Eastward Ho!, having this time seemingly slipped through the net).

Yet as Jonson's career advanced from the late 1590 s he began increasingly to create and assert an authorial identity, a dramatic character resembling and representing himself, a figure who hovers generally just out of sight, almost within earshot, at the very borders of the dramatic action: 'he do not hear me I hope', says Carlo Buffone in Every Man Out

16 'An Expostulation with Inigo Jones', Ungathered Verse, 34. 59-65. 
of His Humour (Grex before Act 1, 342); 'I am looking, lest the poet hear me', says the Stage-Keeper in the Induction to Bartholomew Fair (7-8). This figure of The Author sends his agents and emissaries occasionally forward to speak on his behalf in prologues and epilogues, inductions and choruses, and threatens at times to intervene directly, to walk if need be straight on to the stage, to set matters right. Ben Jonson seems, like Bernard Shaw after him, to have been a disconcertingly close and demanding observer of his own plays in performance, to judge from Sir Vaughan's rebuke to the character of Horace-a thinly disguised representation of Jonson-in Dekker's satiricấl comedy Satiromastix in 1601:

you shall not sit in a galiery, when your comedies and interludes have entered their actions, and there make vile and bad faces at every line, to make sentlemen have a eye to you, and to make players afraid to take your part. $\quad(5.2 .298-301)^{17}$

In the Induction to Jonson's own comedy, Cynthia's Revels, one of the three child actors (who are struggling between themselves as to who is to speak the prologue) asks where the author of the play may be at this moment. One of his companions insists that he is nowhere near at hand; for this author, unlike other authors, always keeps his distance, always behaves decorously behind the scenes:

We are not so officiously befriended by him, as to have his presence in the tiring house, to prompt us aloud, stamp at the book-holder, swear for our properties, curse the poor tire-man, rail the music out of tune, and sweat for every venial trespass we commit, as some author would ... (160-5)

This elaborate denial, markedly at odds with other evidence of Jonson's behaviour in the playhouse, may well have prompted a smile amongst members of the company. Gossip Mirth in Jonson's later comedy, The Staple of News, has glimpsed the author in another mood, 'rolling himself up and down like a tun' in sweaty agitation as he issues last-minute directions to the actors in the tiring-room.

... never did vessel of wort or wine work so! His sweating put me in mind of a good Shroving-dish (and I believe would be taken up for a service of state somewhere, an't were known) - a stewed poet! He doth sit like an unbraced drum with one of his heads beaten out. For that you must note, a poet hath two heads as a drum hath. One for making, the other repeating; and his repeating head is all to pieces... (Induction, 62-70)

${ }^{17}$ Satiromastix, in The Dramatic Works of Thomas Dekker, ed. Fredson Bowers, 4 vols. (Cambridge, 1953-61), 1. 382; text modernised. 
Earlier in his career, at the start of his satirical comedy, Poetaster, Jonson had famously presented a Prologue clad in full armour, who speaks in robust defence of the play's author, and explains his dress as follows:

If any muse why I salute the stage

An armed Prologue, know, 'tis a dangerous age,

Wherein who writes had need present his scenes

Forty-fold proof against the conjuring means

Of base detractors and illiterate apes... (5-9)

In a wry rejoinder to this flamboyant gesture, Shakespeare begins Troilus and Cressida with another Prologue who enters clad in full armour

... but not in confidence

Of author's pen or actor's voice, but suited

In like condition as our argument. (23-50)

'Suited': with this gentle play on words, Shakespeare insinuates his own sense of what may or may not be appropriate to the nature of theatrical representation. ${ }^{18}$ While there is no clear evidence about the way these prologues were originally presented in the theatre, it is tempting to ask if Jonson may not have been inside that suit of armour at the opening of Poetaster, speaking in his own voice about the perils and pains of authorship. Might not Shakespeare, indeed, in answering fashion, have donned that other suit of armour in order to utter the prologue to Troilus and Cressida? This would certainly have been an apt and appropriate piece of company casting. ${ }^{19} \mathrm{It}$ is equally possible that Jonson appeared in his own person at the end of Poetaster, in a highly unusual and complementary scene, the so-called Apologetical Dialogue, that was performed only once in the theatre before being (in the words of the quarto text) 'restrained ... by Authority'. ${ }^{20}$ Here the figure of The Author is discovered in his study, lamenting the ignorance of his audiences and his critics, declaring at some length his total indifference to their opinions, and - in a wonderfully tormented moment of simultaneous self-exposure and retreat-his wish to be left alone.

\footnotetext{
${ }^{18}$ Despite Jonson's seeming hesitations in the epilogue to Cynthia's Revels over the appropriate tone to adopt in an authorial address ('I neither must be faint, remiss, nor sorry, I Sour, serious, confident, nor peremptory, | But betwixt these': 9-11), the epilogue's climatic line-'By (-) 'tis good, and if you like't, you may' - had already attracted mockery. Jonson worries over the line's reception in Poetaster, prologue, 15-20.

${ }^{19}$ I owe the latter suggestion to Professor Jonathan Bate.

${ }^{20}$ 'To the Reader' (Quarto text). The suggestion that Jonson may have played this role is made by A. W. Ward, English Dramatic Literature to the Death of Queen Anne (London, 1899), 2. 360.
} 
Leave me. There's something come into my thought

That must and shall be sung, high and aloof,

Safe from the wolf's black jaw and the dull ass's hoof. (237-9)

Though such a personal appearance by a dramatic author was (to the best of my knowledge) without precedent on the English stage, a similar defence of the authority of the author was a familiar feature of Greek Old Comedy, as Jonson would have known, when the leader of the chorus, in a movement known as parabasis, would come forward (turning aside from the dramatic action) and address the audience directly on behalf of the poet, speaking in his name, praising his work, denigrating the work of rivals, and exhorting the audience to pay attention. ${ }^{21}$ In the Apologetical Dialogue to Poetaster Jonson imports into the English theatre, and aligns himself with, a model of authorship derived partly from the example of Aristophanes and his contemporaries and partly also from 'those great master spirits', the poets of Augustan Rome- - Virgil, Horace, Ovidwho are central characters in the action of his own comedy just ended, Poetaster.

Jonson scatters these small self-portraits throughout his plays in almost Hitchcockian style as a kind of personal signature, a reminder of human agency, of the tenuous but enduring link between artist and artefact. Viewed in one light, they could be seen as a means of maintaining vestigial control over the work which the author has entrusted to the skills of the players and the critical judgement of the play-going public. Viewed another way, they seem to acknowledge, often with some humour, the author's impotence, his inability any longer wholly to direct or possess the work he has brought into being.

When we do give, Alfonso, to the light

A work of ours, we part with our own right;

For then all mouths will judge, and their own way;

The learned have no more privilege than the lay.

Epigrams, 131. 1-4

Jonson wrote these lines to his friend Alfonso Ferrabosco-composer, violist, lutanist, and musical instructor to Prince Henry - on the publication of his musical Lessons in 1609, adding some words of classical con-

${ }^{21}$ See Victor Ehrenberg, The People of Aristophanes: A Sociology of Old Attic Comedy (London and New York, 1943), pp. 32-7; A. M. Bowie, Aristophanes: Myth, Ritual, and Comedy (Cambridge, 1993); Coburn Gum, The Aristophanic Comedies of Ben Jonson: A Comparative Study of Jonson and Aristophanes (The Hague, 1969); Jonson, Poetaster, ed. Tom Cain, Revels Plays (Manchester and New York, 1995), p. 261. 
solation, taken from the writings of Horace and Persius, urging authors to pay no heed to anyone's judgement other than their own. ${ }^{22}$ Giving a creative work 'to the light', whether through publication or performance, parting with the authorial 'right' - - a word of great resonance in his work, anticipating in a moral, if not yet strictly legal sense, the modern notion of intellectual property, of copyright - was always for Jonson a painful if not traumatic act, which he negotiates at times philosophically, at times with sardonic humour. 'When I suffered [the work] to go abroad', Jonson writes of The Masque of Queens, 'I departed with my right; and now, so secure an interpreter I am of my chance, that neither praise nor dispraise shall affect me'.23 'It is further agreed', says the Scrivener in the Induction to Bartholomew Fair, reading out Articles of Agreement with the Author, which purportedly bind the spectators at the Hope Theatre to behave themselves with good sense and decorum,

It is further agreed that every person here have his or their free-will of censure, to like or dislike at their own charge; the author having now departed with his right, it shall be lawful for any man to judge his six penn'orth, his twelve penn'orth, so to his eighteen pence, two shillings, half a crown, to the value of his place-provided always his place get not above his wit. $(85-91)^{24}$

The author: such repeated references-even in humorous contexts such as this - bring into prominence, and confer new status upon, the hitherto obscure writer of the dramatic work. Jonson, one might say, invents the idea of the author-not in the same manner that he may invent such words as 'playwright', 'stage-wright', 'poetaster', terms not hitherto known in English, but as Renaissance rhetoricians understood invention, inventio, as a happy discovery of an already existing term or subject which could be manipulated in a novel way. ${ }^{25}$ The word 'author' was as old as creation itself, its dignity deriving from its evident association with the godhead, 'the author of eternal salvation', 'the author ... of peace', 'the author and finisher of our faith', as the King James Bible has it; 'the author both of life and light', as Jonson himself writes in his

${ }^{22}$ Horace, Epistles, I. 20. 6; Persius, Satires, 1. 7.

${ }^{23}$ This sentence does not appear in the holograph, but is inserted significantly in the published texts, quarto and folio, after line 679.

${ }^{24} \mathrm{Cr}$. Jonson's Fitzdottrel in The Devil is an Ass, as he allows Wittipol to speak without interruption to his wife, Frances Fitzdottrel, for a fixed period of time: 'Speak what you list, that time is yours; my right | I have departed with. But not beyond | A minute or a second look for' (1. 4. $82-4)$.

${ }^{25}$ The $O E D$ 's first recorded instance of word 'poetaster' is from Cynthia's Revels, 2. 4. 11. Jonson discusses inventio in Discoveries, 2161-91; cf. The Underwood, 25. 2 
'Hymn On the Nativity of My Saviour'. ${ }^{26}$ In this regard it resembles those etymologically related terms so favoured by Jonson, 'poet' and 'maker', whose significance Sir Philip Sidney- 'God-like Sidney', as Jonson knowingly calls him (The Forest, 12.91) - had ringingly defended in his Apology for Poetry:

Neither let it be deemed too saucy a comparison to balance the highest point of man's wit with the efficacy of Nature; but rather give right honour to the heavenly Maker of that maker, who having made man to His own likeness, set him beyond and over all the works of that second nature: which in nothing he showeth so much as in Poetry, when with the force of a divine breath he bringeth things forth far surpassing her doings, with no small argument to the incredulous of that first accursed fall of Adam: since our erected wit maketh us know what perfection is, and yet our infected will keepeth us from reaching it. But these arguments will by few be understood, and by fewer granted. Thus much (I hope) will be given me, that the Greeks with some probability of reason gave him the name above all names of learning. ${ }^{27}$..

Sidney's Apology focuses closely on the etymology and inherited significance of the terms associated with poetic activity.

Among the Romans a poet was called vates, which is as much as a diviner, foreseer, or prophet, as by his conjoined words vaticinium and vaticinari is manifest: so heavenly a title did that excellent people bestow upon this heart-ravishing knowledge..$^{28}$

'A Poet is as much to say as a maker', declares George Puttenham in similar fashion at the outset of The Arte of English Poesie in 1589,

And our English name well conformes with the Greeke word: for of poiein to make, they call a maker Poeta. Such as (by way of resemblance and reverently) we may say of God: who without any travell to his divine imagination, made all the world of nought. ... ${ }^{29}$

Jonson inherits this Sidneyan view of the writer's god-like role, whose value was mysteriously expressed through, and vested in, the terminology

${ }^{26}$ Hebrews, 5:9; 1 Corinthians, 14:33; Hebrews, 12:1-2; The Underwood, 1. 3. 1-2. With this last example, cf. Campion's 'Author of light, revive my dying spright', The Works of Thomas Campion, ed. Walter R. Davis (New York, 1970), p. 59.

${ }^{27}$ Sir Philip Sidney, An Apology for Poetry, ed. Geoffrey Shepherd (London, 1965), p. 101.

${ }^{28}$ Sidney, An Apology, ed. Shepherd, p. 98. Jonson similarly sees poets as vates ('priests and poets', The Underwood, 70. 82). Cf. Sir John Harington: 'Prophets and Poets have been thought to have a great affinitie, as the name Vates in Latin doth testifie', A Preface, or rather a Briefe Apologie of Poetrie, and of the Author and Translator prefixed to Orlando Furioso (1591), in G. Gregory Smith (ed.), Elizabethan Critical Essays, 2 vols. (Oxford, 1904), 2. 205.

${ }^{29}$ George Puttenham, The Arte of English Poesie (1589), in Smith (ed.), Elizabethan Critical Essays, 2. 3. 
with which it was traditionally associated. At a time when many of the terms used in relation to literary activity and to the professions more generally in early modern England were still quite fluid and unstable, Jonson's own usage remained remarkably precise and consistent. He distinguished sharply between poets (or makers), on the one hand, and mere versifiers (or rhymers), on the other: 'A rhymer and a poet are two things', as he remarks tartly in Discoveries (lines 2448-9). Samuel Daniel would pass as a rhymer, but not as a poet. ${ }^{30}$ In the Epistle Dedicatory to Volpone Jonson notes that nothing nowadays remains 'of the dignity of poet but the abused name, which every scribe usurps' (lines 34-5), and attempts to set out the true significance of that term. ${ }^{31}$ Jonson described himself at times as a 'maker', but more regularly as a 'poet'. 'In his merry humour he was wont to name himself The Poet', noted Drummond wryly. ${ }^{32}$

'Author' is a word that Jonson employed with a similar care and consciousness of its traditional signification. The Latin root-word, auctor, carried a range of senses ('promoter', 'producer', 'father', 'progenitor', 'originator', 'performer', 'authority', 'teacher', 'counsellor', 'advisor', etc.) as well as the sense that has come to dominate its modern English derivative: 'writer'. In Renaissance usage, the words auctor and 'author' might signify the patron or enabler of an artistic work, as well as the actual artist. Thus Lorenzo de' Medici (for example) was described as the auctor, the author, of the church of San Gallo in Florence; a usage which, as F. W. Kent observes, 'may imply that Lorenzo was both entrepreneurially and creatively involved in its construction', though 'architectural historians almost unanimously attribute its design to Giuliano da Sangallo. ${ }^{33}$ In a similar fashion the Venetian ambassador who witnessed a performance at court of .Jonson's Masque of Beauty described Queen Anne, who commissioned and danced in the masque, as 'the authoress of

${ }^{30}$ Jonson told William Drummond of Hawthornden that 'Samuel Daniel was a good honest man, had no children, but no poet' (Conversations with Drummond, lines 23-4). Earlier he had written that the Countess of Bedford, in giving her patronage to Daniel, was thought to have 'a better verser got / (Or "poet", in the court account) than I ...' (The Forest, 12. 68-9). Mercury remarks of Hedon in Cynthia's Revels (Q), 2. 1.45-9 that 'he loves to have a fencer, a pedant, and a musician seen in his lodging a-mornings'. Cupid: 'And not a poet?' Mercury: 'Fie, no; himself is a rhymer, and that's a thought better than a poet.'

${ }^{31}$ Discoveries, 2346 ff., Epigrams, 10, Every Man Out of His Humour, 3. 6. 209, The Staple of News, Prologue for the Stage, 5.

${ }^{32}$ Conversations, line 636. The term jocularly recalled the familiar styling of Aristotle as 'The Philosopher'.

${ }^{33}$ F. W. Kent, Lorenzo de' Medici and the Art of Magnificence (Baltimore and London, 2004), p. 98 . 
the whole'. ${ }^{34}$ Jonson himself used the word in relation to non-textual, as well as textual artistry: 'The author was Master Thomas Giles', he writes, when describing the intricate dances devised for The Masque of Queens (line 638). ${ }^{35}$

Significantly, however, Jonson chose never to use the term 'author' in relation to his colleague, Inigo Jones, despite the two men's close and brilliant collaborations at court. When In-and-In Medlay in Jonson's late comedy, $A$ Tale of a Tub-a character obviously representing Inigo Jones-claims he is the 'author' of a village puppet-show, he is sharply contradicted by his companion Squire Tub, who tells him he is merely the 'workman' or 'artificer' ( $A$ Tale of a Tub, 5. 7. 22-3). The comic dispute about the nature of authorship in this comedy mirrors the real life dispute between Jonson and Jones as to which of them was the true or primary 'inventor' of the masques which they collaboratively brought into being (Medlay in $A$ Tale of $a$ Tub 'must be sole inventor', grumbles the 'great writer', D'ogenes Scriben, 5. 2. 37) ${ }^{36}$ Jonson was equally reserved about Jones's adoption of the term 'architect' to designate his profession. Like 'author', 'poet', 'maker', the word architect seemed to carry-presumptuously, in Jonson's view - a suggestion of divine power, for God himself was known as 'the great architect', as Raphael was to call him in Paradise Lost (8. 72). Even in non-Christian contexts, the word 'architecture' and its cognates had developed special connotations. Architectonike was the term used by Aristotle to describe the ultimate end to which all knowledge was directed and subordinate, namely, virtuous action. Jones's 'Almighty architecture', "on the other hand, was for Jonson not simply

${ }^{34}$ Calendar of State Papers (Venetian) 1607-10, p. 86. I am grateful to Professor Martin Butler for this reference. With a playful consciousness of the family's literary reputation, Jonson similarly describes the Sidneys as 'authors of the feast' designed to celebrate the twenty-first birthday of Sir William Sidney: The Forest, 14. 10.

${ }^{35}$ Describing the dances in Hymenaei, Jonson writes: 'Here they danced forth a most neat and curious measure, full of subtlety and device, which was so excellently performed as it seemed to take away that spirit from the invention, which the invention gave to it; and left it doubtful whether the forms flowed more perfectly from the author's brain or their feet' (310-14). Here Jonson's prose leaves it equally and appropriately doubtful whether 'the author' on this occasion is Jonson himself or his choreographer.

${ }^{36}$ Jones had objected to his name appearing after Jonson's on the title-page of Love's Triumph Through Callipolis in 1631 ('The Inventors, Ben Jonson, Inigo Jones'). Jonson responded by omitting Jones's name altogether from the title-page of Chloridia, and by writing An Expostulation with Inigo Jones' and two other satirical poems about his collaborator. On the intellectual background to the dispute, see D. J. Gordon, 'Poet and Architect: The Intellectual Setting of the Quarrel between Ben Jonson and Inigo Jones', in Stephen Orgel (ed.), The Renaissance Imagination (Berkeley, Los Angeles, and London, 1975). 
devoid of ethical content; it was mere technical work, a kind of trade dangerously close to bricklaying. ${ }^{37}$

The precise meaning of the word author continued to attract discussion during Jonson's lifetime. In Thomas Hobbes's account 'Of Persons, Authors, and things personated' in chapter 16 of Leviathan the author is seen as the ultimate owner and authoriser of words or actions that might however be spoken or negotiated or personated on his behalf by someone else, who is variously described by Hobbes as a persona, a person, an actor.

The word Person is latine; instead whereof the Greeks have prosopon, which signifies the Face, as Persona in latine signifies the disguise, or outward appearance of a man, counterfeited on the Stage; and sometimes more particularly that part of it, which disguiseth the face, as a Mask or Visard: And from the Stage, hath been translated to any Representer of speech and action, as well in Tribunalls, as Theaters. ${ }^{38}$

Hobbes is here exploring a question that lay at the very heart of contemporary political and religious debate: where civil authority ultimately lay. Quentin Skinner, in an acute analysis of this section of Leviathan, points to a curious oddity in Hobbes's use of the theatrical analogy, for in the theatre of Hobbes's time ultimate authority lay not with the author but with the regulating officer, acting on the monarch's behalf, who licensed plays for theatrical performance: the Master of the Revels. ${ }^{39}$ Jonson, oddly enough, had been granted the reversion of this post in 1621; while he never finally inherited this position, he was well acquainted with its mode of operation, and with the conflicting kinds of 'authority' (legal, authorial, popular, etc.) that vied for supremacy within the theatre of his time. ${ }^{40}$ According to John Aubrey, Jonson was Hobbes's 'loving and familiar friend and acquaintance' and closely associated with him and his

37 'An Expostulation with Inigo Jones', lines 10, 92. Jonson's references to architects and architecture are generally disparaging: cf. The Underwood, 77. 25; The Staple of News, 4. 2. 35-7; Discoveries, 1135. See also A. W. Johnson, Ben Jonson: Poaty and Architecture (Oxford, 1994).

${ }^{38}$ Thomas Hobbes, Leviathan, ed. Richard Tuck (Cambridge, 1991).

${ }^{39}$ Quentin Skinner, 'Hobbes and the Purely Artificial Person of the State', in Visions of Politics, vol. 3, Hobbes and Civil Science (Cambridge, 2002), 177-208. I am grateful to Professor Skinner for guidance on this passage. See also Christopher Pye, 'The Sovereign, the Theater, and the Kingdome of Darknesse: Hobbes and the Spectacle of Power' in Stephen Greenblatt (ed.), Representing the English Renaissance (Berkeley, Los Angeles, and London, 1988), pp. 279-301; and David Runciman, Pluralism and the Personality of the State (Cambridge, 1997), chaps. 2, 11. ${ }^{40}$ See Richard Dutton, Mastering the Revels: The Regulation and Censorship of English Renaissance Drama (Houndmills, Basingstoke, 1991); Richard Burt, Licensed by Authority: Ben Jonson and the Discourses of Censorship (Ithaca and London, 1993). 
intellectual circle during the 1620 s and $1630 \mathrm{~s}^{41}$ It is tempting to wonder if Hobbes's thinking on the question of authorship may not have been stimulated by his familiarity with Jonson's own dramatic practice, and even conceivably through conversations with Jonson himself. A comedy such as Bartholomew Fair explores the very terrain of chapter 16 of Leviathan, asking where authority finally rests both within the theatre and in society at large, presenting an array of petty officials who serve as agents or deputies-persons, in Hobbes's terminology-who act on delegated authority, claiming, in a wild collision of conflicting interests, licence or warrant for their actions. The authority they claim derives variously from the Judge of Pie Powders, from a guardian, from a husband, from the king, from the commonwealth, from scripture, from the Master of the Revels. 'Sir, I present nothing but"what is licensed by authority', protests the puppeteer, Lantern Leatherhead, as the Puritan Zeal-of-the-Land Busy angrily demolishes his show. 'Thou art all licence, even licentiousness itself, Shimei!', exclaims Busy. 'I have the Master of the Revels' hand for't, sir', responds Leatherhead. 'The Master of Rebels' hand, thou hast', says Busy: 'Satan's' (5. 5. 14-20). In an epilogue written for performance of the play at Court, Jonson makes it clear that final authority, the ultimate licence or warrant for what is allowed in the kingdom, is firmly vested in King James himself. ${ }^{42}$

When Bartholomew Fair was performed before King James in 1614, Shakespeare had already retired to Stratford upon Avon, having made, in what must seem to modern eyes an astonishing act of neglect or renunciation, no apparent effort to bring his works together in collected form, to present a Shakespearian canon to the world. Jonson's attitude to publication differed from that of Shakespeare in a number of obvious ways. From his earliest professional years Jonson had methodically prepared quarto editions of his individual plays - including, defiantly, those which had not succeeded in the theatre, and those over which he had, legally speaking (as Joseph Lowenstein has shown in remarkable detail) no formal rights of ownership-confidently proclaiming his authorship on the title pages. ${ }^{43}$ The traditional belief that Shakespeare and the theatrical

${ }^{41}$ Aubrey's 'Brief Lives', ed. A. Clark, 2 vols. (Oxford, 1898), 1. 365.

42 Jonson's use of authorial delegates-characters who speak on the author's behalf-closely anticipates the role that Hobbes attributes to the persona: 'if you please to confer with our author by attorney, you may sir', comments one of the boys in the Induction to Cynthia's Revels (136-7), 'our proper self here stands for him'. Cf. The Magnetic Lady, Induction, 14-16.

${ }^{43}$ Joseph Loewenstein, Jonson and Possessive Authorship (Cambridge, 2002); 'The Script in the Marketplace', in Greenblatt (ed.), Representing the English Renaissance, pp. 265-78; and The 
company for which he worked were, by way of contrast, wholly indifferent or opposed to publication of play texts has been sharply challenged in recent years. During the early part at least of Shakespeare's career - as Lukas Erne has persuasively argued in an important revisionist studyShakespeare and the Lord Chamberlain's Men seem to have regarded the publication of his plays in quarto format as conducive to their commercial success in the playhouse, rather than prejudicial. While the company normally left an interval of about two years between first performance of a play and its entry in the Stationers' Register, it seems to have found publication a useful means of reviving theatrical interest in plays that were no longer entirely new in performance. Of the first dozen or so plays that Shakespeare wrote for the Chamberlain's Men, as Erne points out, 'not a single one that could legally have been printed remained unprinted by 1602'. Many of these quartos carried the author's name, as Jonson's did. ${ }^{44}$ Yet the evidence for Shakespeare's continuing interest in the publication of plays during the latter part of his career (post-1602) is less coherent and less compelling; and the notion that he may have begun to prepare a collected edition of his writings during his final years in Stratford remains entirely speculative, and based in part on dubious anecdote. If Shakespeare, early in his career, shrewdly perceived that publication of his plays might be of practical advantage to his company, it is none the less difficult to see him as driven by the same authorial imperative, the same systematic recourse to the medium of print, that Jonson's lifelong record of publishing seems to imply. ${ }^{45}$

In 1616, the year of Shakespeare's death, the printer and bookseller William Stansby produced under Jonson's watchful eye a folio collection

Author's Due: Printing and the Prehistory of Copyright (Chicago, 2002). See also Douglas A. Brooks, From Playhouse to Printing House: Draña and Authorship in Early Modern England (Cambridge, 2000).

${ }^{44}$ Lukas Erne, Shakespeare as Literary Dramatist (Cambridge, 2003); the passage quoted is from p. 86. Erne (chap. 2) corrects Douglas Brooks's mistaken assertion (From Playhouse to Printing House, pp. 71 and passim) that the quarto title-page of 2 Henry IV in 1600 was the first to attribute authorship to Shakespeare: it was in fact the sixth such attribution. Peter W. M. Blayney speculates that peaks in publication of playbooks between December 1593 and May 1595 and May 1600 to October 1601 may suggest a deliberate strategy of 'publicity' or 'advertising' of plays for the theatre: 'The Publication of Playbooks', chap. 21 in John D. Cox and David Scott Kastan (eds.), A New History of Early English Drama (New York, 1997), pp. 383-422, at p. 386.

${ }^{45}$ Jonson was none the less sharply ambivalent in relation to the print culture of his day: see Ian Donaldson, 'Jonson's Poetry', in The Cambridge Companion to Ben Jonson (Cambridge, 2000), chap. 9, esp. pp. 120-3, and the revealing analysis of manuscript circulation offered by Colin Burrow in his forthcoming edition of the poems in The Cambridge Edition of the Works of Ben Jonson. 
of The Works of Benjamin Jonson: a volume comprising more than a dozen Court masques, a handful of entertainments, a panegyrical address to King James on his entry to the first session of parliament in 1604, two substantial collections of verse, and - most controversially - a group of nine plays, a kind of writing seldom before included in England in any volume bearing the serious title Works. 'Pray tell me, Ben', wrote one wag later, 'where doth the mystery lurk, | What others call a play you call a worke'. ${ }^{46}$ Yet through the 1616 folio, modelled as it was in part on Renaissance editions of classical authors, and in part on the great folio edition of King James's work $\vec{k}$ s published earlier that same year, Jonson was signalling his wish to elevate drama to a more serious literary status, and to present himself as no mere playwright, but as an author of classical range, dignity, and proportion.

This annual lecture recognises Shakespeare's undisputed genius, his unrivalled standing in the field of English literature. That modern consensus is in no way diminished if we recall that during the century or so following his death it was not William Shakespeare but Ben Jonson who was reckoned by many good judges to have been the greatest writer England had ever produced. ${ }^{47}$ Such a verdict, however fantastical it may appear to later generations, was perhaps in part encouraged by Jonson's more forward style of self-presentation, which I have tried to illustrate here; and validated in part by Jonson's sheer versatility and ambition as a writer, venturing as he did into so many branches of humanistic learning: as poet, as deviser of Court and civic entertainments, as dramatist, as historian, philologist, rhetorician, as writer on statecraft, social conduct, theology, as England's first literary critic worthy of the name. Jonson too in his own fashion was a great factotum, a Dominus Do-All, but he found a more flattering name to describe his chosen role, and that name was Author.

When in the early 1620s members of Shakespeare's old company, heading off a venture from a rival bookseller, began to prepare for publi-

${ }^{46}$ Wit's Recreation (1640). Plays by both Gascoigne and Daniel had previously appeared in volumes entitled 'Works': Erne, Shakespeare as Literary Dramatist, p. 45. See also Ian Donaldson, 'Collecting Ben Jonson' in Andrew Nash (ed.), The Culture of Collected Editions (Houndmills, Basingstoke, 2003), pp. 19-31; and Ben Jonson's 1616 Folio, ed. Jennifer Brady and W. H. Herendeen (Newark, London, and Toronto, 1991), which includes Sara van den Berg's 'Ben Jonson and the Ideology of Authorship', pp. 111-37.

${ }^{47}$ G. E. Bentley, Shakespeare and Jonson: Their Reputations in the Seventeenth Century Compared, 2 vols. (Chicago, 1945). Bentley's methodology has been questioned, most notably by David L. Frost in The School of Shakespeare (Cambridge, 1968), but the evidence he assembles still supports this general conclusion. 
cation a collected folio edition of his dramatic works, they were assisted by Jonson himself, who prepared two poems which stand at the head of the 1623 First Folio. He may also-as numerous small stylistic touches suggest-have drafted the famous address 'To the great Variety of Readers' that is signed by the players John Heminge and Henry Condell:48

It had bene a thing, we confesse, worthie to have bene wished, that the Author himselfe had liu'd to set forth, and ouerseen his owne writings; But since it hath bin ordain'd otherwise, and he by death departed from that right, we pray you do not envie his Friends, the office of their care, and paine, to haue collected \& publish'd them ...

'The Author himselfe': Shakespeare here is dignified with the styling that, throughout his lifetime, he was generally reluctant to adopt, but that is now emphatically accorded to him by his friends, to whom the 'right' of publication has passed.

That styling is repeated in the title of Jonson's poem 'To the Memory of My Beloved, The Author, Mr William Shakespeare, and What $\mathrm{He}$ Hath Left Us', in which those words, THE AUTHOR, are significantly emphasised in large-sized upper-case typography. Jonson's poem places Shakespeare above all other English writers for the stage, alongside the greatest dramatic authors of antiquity, Aeschylus, Euripides, Sophocles, Seneca; hailing him as a 'Starre of Poets', now standing high in the heavens, visible and illuminating to all. The dramatic author is no longer an anonymous backroom boy, but has become at last a star. In another brief poem accompanying Martin Droeshout's famous engraving of Shakespeare, Jonson vouches for the likeness of the portrait, but urges the reader to study not Shakespeare's picture but his book, through which his personality is expressed, and his life continues. Jonson's two poems at the head of the 1623 folio have proved over the years to be the most formidable barrier to those wishing to "prove that Shakespeare was not Shakespeare, but somebody else; to assert that no real evidence exists to link the player from Stratford to the works attributed to him. A not uncritical appraiser of his greatest colleague's writings, Jonson could scarcely have expressed himself more clearly or unambiguously than he does on this occasion, affirming that this man, known and beloved by him, pictured in the accompanying illustration, was indeed 'THE AUTHOR' of the works this volume contains.

${ }^{48}$ For a more detailed discussion of this possibility (first proposed by George Steevens) see Ian Donaldson, Jonson's Magic Houses (Oxford, 1997), p. 19 and n. 34. 
In death as in life, Ben Jonson and William Shakespeare are intimately linked through these verses in the opening pages of the 1623 Folio; a book which, together with Jonson's own 1616 Folio, was to become a foundational volume in the history of collected editions in England, much imitated and emulated in the years to come, and in the establishment of Shakespeare's own reputation as a writer, in Jonson's own phrase-astonishingly predictive in 1623 - 'not of an age, but for all time'. The volume may also be seen as a landmark in the history of authorship itself; as what one might term, in homage to Roland Barthes, Michel Foucault, and much vexed textual argumentation still to come, the birth of the author. ${ }^{49}$

Note. I am most grateful to Professors Martin Butler and Quentin Skinner for stimulating help and advice during the preparation of this lecture.

${ }^{49}$ See Richard Dutton, 'The Birth of the Author' in R. B. Parker and S. P. Zitner (eds.), Elizabethan Theater: Essays in Honor of S. Schoenbaum (Newark and London, 1996), pp. 71-92. 


\section{University Library}

\section{- M M I N E R VA A gateway to Melbourne's research publications}

Minerva Access is the Institutional Repository of The University of Melbourne

Author/s:

DONALDSON, I

Title:

Shakespeare, Jonson and the Invention of the Author

Date:

2007

Citation:

DONALDSON, I. (2007). Shakespeare, Jonson and the Invention of the Author. Proceedings of the British Academy, Volume 151, 2006 Lectures, (1), pp.319-338. Oxford University Press.

Persistent Link:

http://hdl.handle.net/11343/31289 